\title{
SCIDoC
}

\author{
International Journal of Ophthalmology \& Eye Science (IJOES) \\ ISSN: 2332-290X
}

\section{Intraoperative Injection of Triamcinolone Acetonide in External Dacryocystorhinostomy}

Vasu N Naik ${ }^{1 *}$, Vijay Kumar ${ }^{2}$

${ }^{1}$ Ophthalmology Department, District Hospital, NHM, District Health and Family Welfare Office, Chamarajanagara District, Karnataka, India.

${ }^{2}$ Malleswaram Eye Hospital, 1 Floor, Radha Building, Sampige Road Malleswaram Circle, Banglore, Karnataka, India.

\section{Abstract}

Aim: A prospective and interventional study to known the efficacy and complications of intraoperative triamcinolone acetonide (TMA) $40 \mathrm{mg} / \mathrm{ml}$ injection in primary external dacrycystorhinostomy ( EXDCR)

Material and Methods: Clinically confirmed 38 cases of primary acquired nasolacrimal duct obstruction (PANDO) are randomly grouped as A (Study group) with 20 cases and B (Control group) with 18 cases. Both group underwent primary EXDCR with silicone tube(ST) intubation. Group A cases received $0.5 \mathrm{ml}$ of TMA $40 \mathrm{mg} / \mathrm{ml}$ and group B $0.5 \mathrm{ml}$ of Gentamycin $40 \mathrm{mg} / \mathrm{ml}$ injection intraoperatively. Resolution of symptoms and complications of TMA injection are evaluated at 6 months follow up.

Result: Mean age, gender and laterality of the eye involvement are not different between two group. The success rate in group A is $90 \%(18 / 20)$ and group B $88.9 \%$ (16/18), the difference is very small $(\mathrm{P}=1.0)$. Raised IOP (Intraocular pressure ) of $>18 \mathrm{mmHg}$ observed in $10 \%(2 / 20)$ cases of group A. Group A cases had minimal post operative wound inflammation $80 \%(16 / 20)$ compare to $44 \%(8 / 18)$ cases in group B. $(\mathrm{P}=0.04)$. Early resolution with cosmetically good scar seen in $90 \%$ $(18 / 20)$ in group A compare to $55.5 \%(10 / 18)$ cases in group $\mathrm{B}(\mathrm{P}=0.02)$.

Discussion: Intraoperative TMA injection does not improve the success rate of primary EXDCR in PANDO. But significantly reduces the immediate postoperative wound inflammation and facilitates early resolution of the wound scar. Raised IOP is a concern in TMA injection group.

Keywords: Benefits; Complications; EXDCR; Triamcinolone.

\section{Introduction}

Epiphora, discharge and painless swelling in the medial canthal area are the common presentations of primary acquired nasolacrimal duct obstruction (PANDO) [1, 2]. The gold standard treatment for PANDO is external dacryocystorhinostomy (EXDCR) with success rate of $59 \%-99 \%$ [3-6].

Various factors have been blamed for the failure of EXDCR. Absence of adequate size flaps in anastomosis, reduced size of osteotomy opening, fibrotic closing of the common canalicular opening, intra nasal synechia, narrowing or the closure of the osteal opening, abnormal position of the lacrimal sac wall and nasal mucosal anastomosis, granuloma formation at the inner opening of the anastomosis, exposed bony margin facilitating granula- tion tissue formation and racial people with higher melanin in the body $[2,5,7-11]$.

Many modalities and modifications have been studied to overcome these predisposing factors. Altering the number of dacrycystorhinostomy (DCR) flaps and increasing the size of osteotomy [8, 12], intraoperative use of Mansoura T tube [13], silicone tube intubation $[3,4,14]$, use of antifibrotic agents like Mitomycin C (MMC), 5-Flurouracil and depot steroids [9-11, 15].

Depot steroid, Triamcinolone acetonide (TMA) has been widely used in many ophthalmic diseases and procedures. As intralesional injection in medical management of chalazion [16, 17], as retobulbar injection in management of non responding dysthyroid proptosis [18], in management of diabetic macular oedema [19], for visualizing Vitreous during vitrectomy [20], and in treatment

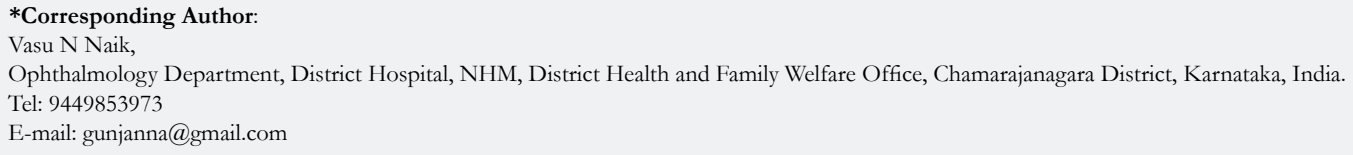

Copyright: Vasu $\mathbf{N}$ Naik ${ }^{\circ}$ 2020. This is an open-access article distributed under the terms of the Creative Commons Attribution License, which permits unrestricted use, distribution and reproduction in any medium, provided the original author and source are credited. 
periocular scars [21]. Considering its anti inflammatory and antifbrotic action a hypothesis was made that intra operative depot steroid TMA may reduce the post operative inflammation related complications and improve the success rate of EXDCR in PANDO.

\section{Material and Method}

This is a prospective, comparative and interventional study done in the District Hospital Chamarajanagara in Karnataka state. This study was carried from August 2017 to July 2019. The study was approved by the review and ethical committee of the hospital. All patients were informed about the merits and demerits of the study and written consent was taken. The study adhered to declaration of Helsinki 1975. Two group were made, Group A (study group) undergoing EXDCR + silicone tube intubation with intraoperative $0.50 \mathrm{ml}$ of undiluted TMA $40 \mathrm{mg} / \mathrm{ml}$ depot steroid injection (Aurocort, Aurolab, Madurai, India) and Group B (control group) undergoing EXCDR + silicone tube intubation with intraoperative $0.50 \mathrm{ml}$ of Gentamycin $40 \mathrm{mg} / \mathrm{ml}$ injection. (Gentalab, Laborate Pharmaceutical India Ltd. Patna Sahib, India).

All enrolled patients' demography and detailed history was recorded. All patients under went comprehensive eye examination. Lacrimal duct system related diagnostic probe test, syringing, Fluorescein Dye Disappearance(FDD) test are done. For tear function Schirmer test and Break Up Time( BUT) were also done. Based on probe test, syringing and FDD test PANDO was confirmed. Patients were randomly allotted into study group and control group. Exclusion criteria are acquired secondary nasolacrimal duct block, punctual stenosis, trichiasis, entropion, ectropion, lag ophthalmos, chronic blapheritis, dry eye, corneal surface disorder. Patients with comorbid systemic diseases, nasal pathology and age group below 18 years were excluded from study.

All Patients were operated from single surgeon .Surgical steps of EXDCR are as described by Dupuy - Dutemps and Bourget modified with only single anterior flap in lacrimal sac and nasal mucosa $[8,12]$. Under sterile condition surgical area infiltrated with 2:1 ratio mixtured of $2 \%$ lidocaine and $0.5 \%$ bupivacaine. Nasal pack done with $1.25 \mathrm{~cm}$ size ribbon gauze soaked in $30 \mathrm{ml}$ $4 \%$ xylocaine with 2 ampule of adrenaline 1:10000 and left till the time of silicone stenting. A curved 10-12 mm size incision 8-10 $\mathrm{mm}$ from medial canthus taken all along the direction of anterior lacrimal crest starting from middle point of the medial palpebral ligament. Layer by layer skin, subcutaneous tissue, orbicularis oculi were separated to expose the medial end of medial palpebral ligament. The Medial palpebral ligament disinserted. Lamina papyracea was gently perforated with bone rongue. Around $10-15$ $\mathrm{mm}$ diameter size osteotomy done with serial sized bone rounge. With the Bowmans probe 00 medial wall of lacrimal sac tented and single large anterior flap was made. Same size anterior flap made in nasal mucousa.A bicanalicular Silicone tube (Aurolacfrom Aurolab, Madurai, India) intubated through upper and lower pucta, retrieved through common canaliculi, osteotomy and into nasal cavity. Two ends of the tube were tied in such way that there is no snaring effect on punctae, unnecessary looping into medial fornix or hanging out of the nostril. Tied end of the tube left free in the nasal cavity at the inferior turbinate level. Both the flap were trimmed as per the requirement and joined together with 60 vicryl. At this point undiluted $0.50 \mathrm{ml}$ of TMA $40 \mathrm{mg} /$ $\mathrm{ml}$ injection in group A and $0.50 \mathrm{ml}$ of Gentamycin(GM) 40mg/ $\mathrm{ml}$ injection in group B was injected. Injection of $0.30-0.40 \mathrm{ml}$ was given all around the bony opening between nasal mucosa and bone endostium and 0.1 to $0.2 \mathrm{ml}$ to fill the empty space above the anastomosis. Palpebral ligament refixed, orbicularis muscle and skin were closed. For all suturing 6- 0 vicryl used . Fresh nasal pack and pad bandage applied.

Post operatively all patients received oral Dcilofenac + paracetamol, cefixime $200 \mathrm{mg}$ twice daily for 5 days. Topically antibiotic drops five times daily in group A and antibiotic steroid drops five times daily in group B. Antibiotic ointment application over the wound two times daily in both group. Follow up done on 1 day, 1 week, 4 week and monthly for 6 months. Nasal pack was removed on first post operative day, skin sutures on 10th day and silicone tube was removed between $12-24$ weeks post operatively. During each visit patients were evaluated for the success and complications of the procedure. Success of the procedure was considered when both subjective and objective resolution of PANDO. Subjectively resolution of epiphora, discharge or swelling. Objectively by anatomical and functional patency of anastomosis by syringing and FDD test respectively.

The results are analyzed by NCSS 2020 Statistical Software (2020). NCSS, LLC. Kaysville, Utah, USA and The results are presented with group mean compared with two tailed Fishers exact test and statically significance by actual $P$ value.

\section{Results}

There were 38 eyes from 38 patients. Mean age of the patients is $48.8+/-.15 .4(20-72)$ yrs. Female male ratio is $1.5: 1$. Right eye was involved in $47.4 \%(18 / 38)$ patients and left eye in $52.6 \%$ ( $20 / 38$ ) patients and difference is very narrow $(\mathrm{P}=0.35)$. Common presentation was epiphora in $73.6 \%$ ( 28/38) patients, mucopurulent discharge in $18.4 \%(7 / 38)$ and mucocele in $8 \%(3 / 38)$ patients .Mean duration of presentation is $9.2(13-38)$ months.

Around 89.5\% (34/38) patients were having both subjective and objective resolution of symptoms (epiphora/discharge/mucocele) at the end of 6 months. Only 10.5\% (4/38) patients had no resolution of the symptoms both subjectively and objectively. In $5.3 \%(2 / 38)$ patients IOP was raised $>15 \mathrm{mmHg}$ from base line reading during the follow up period.

There were 20 patients in group A and 18 patients in group B. Mean age of group A patients was $46.5+/-15.3$ and appears to be younger than mean age of group B patients 51.6+/-15.6 yrs, but the difference is very small and not relevant $(\mathrm{P}=0.35)$ There is no much difference in the gender affection female : male ratio was $1.5: 1$ and 1.6:1( $P=1.00)$, laterality of the affected eye $R / E$ : $\mathrm{L} / \mathrm{E} 11: 9$ and 7:11 $(\mathrm{P}=0.35)$ respectively between group $\mathrm{A}$ and B. There is no difference in the Presenting symptoms and duration of symptoms between two groups. $(\mathrm{P}=0.71)$. (Table 1). On comparing the success rate between two group, in group A $90 \%$ $(18 / 20)$ cases and in group B 88.9\% (16/18) cases were having subjective and objective resolution of symptoms at the end 6 months and the difference is to small $(\mathrm{P}=1.00)$.

There were $10 \%(2 / 20)$ cases of failure in group A. Both after the removal of the stent at $4^{\text {th }}$ month follow up and underwent 
Table 1. Demographic details of patients, Eye involvement, presenting symptoms and duration of Symptoms.

\begin{tabular}{|c|c|c|c|c|}
\hline & Total $\mathbf{( n = 3 8 )}$ & $\begin{array}{c}\text { Group A } \\
(\mathbf{n = 2 0 )}\end{array}$ & $\begin{array}{c}\text { Group B } \\
(\mathbf{n}=\mathbf{1 8})\end{array}$ & P value \\
\hline Age (years) standard deviation & $48.3+/-16.4$ & $46.6+/-15.3$ & $51.6+/-15.6$ & $\mathrm{P}=0.31$ \\
\hline Female / Male & $23 / 15$ & $12 / 8$ & $11 / 7$ & $\mathrm{P}=1.00$ \\
\hline Right eye/Left eye & $20 / 18$ & $11 / 9$ & $9 / 9$ & $\mathrm{P}=0.35$ \\
\hline Epiphora & 28 & 14 & 14 & $\mathrm{P}=0.35$ \\
Discharge/ Mucocele & 10 & 6 & 4 & $\mathrm{P}=0.35$ \\
\hline Duration of Synptoms & $\begin{array}{c}9.2 \text { months } \\
(4-14)\end{array}$ & $\begin{array}{c}9.2 \text { months } \\
(4-14)\end{array}$ & $\begin{array}{c}8.8 \text { months } \\
(5-14)\end{array}$ & $\mathrm{P}=1.00$ \\
\hline
\end{tabular}

re-intubation of the stent. In group B the procedure was failed in $11.1 \%(2 / 18)$ cases. These two cases had adhesion in the nasal cavity with the stent in situ on $3^{\text {rd }}$ month follow up. Both the cases received $0.50 \mathrm{ml}$ of TMA $40 \mathrm{mg} / \mathrm{ml}$ injection and both cases had resolution of symptoms. All These 4 cases were treated as failed cases.

In group A $10 \%(2 / 20)$ cases had raised IOP. One case on $2^{\text {nd }}$ month follow up period. Applanation IOP was $>15 \mathrm{mmHg}$ more than base line IOP and controlled with topical Beta blocker, after 6 weeks treatment IOP stabilized to $<21 \mathrm{mmHg}$. Another patient on 3rd month follow up. The raise was $>22 \mathrm{~mm}$ of $\mathrm{Hg}$ from base line IOP and controlled with Beta blocker and alpha agonist to < $21 \mathrm{~mm} \mathrm{Hg}$ and patient converted to steroid induced glaucoma.

Other observations we have observed in this study was minimal post operative inflammation around the incision wound in $80 \%$ $(16 / 20)$ cases in group A compare to group B 44\% (8/18) with wide difference between two groups $(\mathrm{P}=0.04)$. It is to be remembered that we have not used topical steroid drop in group A patients for 6 weeks and the local anti-inflammatory effect was taken care by depot steroid. Regarding the wound related scar it was cosmetically invisible in $90 \%(18 / 20)$ cases in group A and $56 \%$ $(10 / 18)$ in group $\mathrm{B}$ and the difference is large. $(\mathrm{P}=0.02)$.(Table .2) (Composite Figure .1)

\section{Discussion}

Depot steroid, TMA is a synthetic corticosteroid having 5 times anti-inflammatory action compare to hydrocortisone. It is a long acting anti-inflammatory, Anti Vascular endothelial growth factor (VEGF) and antifibrotic agent. Mode of action is on chemical mediators by inhibiting phospholipase A2 which in turn prevents the synthesis of thormbaxane A, prostaglandins and leukotrenes. Also it is a inhibitor of inflammatory cells, inhibitor of VEGF gene and reduces the capillary permeability. These functions reduces exudation of plasma fluids, controls the fibroblast proliferation and regulates collagen deposit [21, 22]. An assumption was made that intraoperative depot steroid may reduces the inflammation, prevents granulation tissue formation, minimizes the fibrosis and scar formation after EXDCR in cases of PANDO.

The mean age of the patients was 48.8 (20-72) yrs. This study had more younger patients compare to previous report of mean age of $56 \mathrm{yrs}[8,13]$ and the difeerence is small $(\mathrm{P}=0.25)$ Majority of our patients were from rural area and farmers . Constant exposure to irritants like sun light, pollens, animal hairs and dust particles are known to alter the chemical composition of tear and nasal secretion. These altered composition cause anatomical changes in mucosal lining of the lacrimal drainage system and nasal mucosal epithelium. These factors indirectly affect the cavernous plexus as follows: descending inflammation from the eye or ascending inflammation from the region of the nose may initiate malfunctions in the cavernous body with reactive hyperemia, swelling of the mucous membrane, and temporary occlusion of the lacrimal passage. Then, repeated isolated episodes of dacryocystitis may lead to structural epithelial and subepithelial changes. Loss of typical goblet and epithelial cells, which plays an important role in the tear-outflow mechanism, as well as fibrosis of the helical system of connective tissue fibers in the area of the lacrimal sac and nasolacrimal duct. Addition to this there is reduction and destruction of specialized blood vessels of the cavernous body leading to malfunctions of the tear-outflow mechanism and the vicious circle continues $[1,2]$. This may be the reason for more number of younger patients developing PANDO in our study. On gender involvement female - male ratio was 1.5:1 and this is comparable to earlier observation of PANDO is more common in females [3, 4]. This study did not find any difference in the right eye and Left eye involvement of PANDO 52.64\% (20/38) and 47.36\% (18/38 ) respectively $(\mathrm{P}=0.35)$.

Epiphora was the common symptoms in our study $73.68 \%$ $(28 / 38$ cases $)$ this is in concordance with earlier reports $[3,4,13]$. The observed success rate of $89.47 \%$ ( $34 / 38$ ) in our study is comparable with previous reports $[4,5,13]$.

The mean age, gender involvement, laterality of the eye involvement and duration of symptoms are not different between two group (Table.1).

With the available literature common factors for failed EXDCR are fibrotic block of the common canalicular opening, adhesion in the nasal cavity and closure of the osteal opening by granulation tissue $[1,2]$. Depot steroid TMA is known to reduce the inflammation, granulation tissue formation and fibrotic tissue [9]. The assumption in the beginning of this study was the depot steroid should improve the success rate of EXDCR in TMA received group compare to GM injection received group.

The success rate in study group was $90 \%(18 / 20)$ compare to control group $89 \%$ ( $16 / 18$ ) with small difference $(\mathrm{P}=1.0)$. This success rate of $90 \%(18 / 20)$ is comparable to previous study report [11]. Aerin et al., [11] in their prospective study, 45 patients with PANDO underwent endonasal DCR. During the follow up period various type of granuloma developed at various location of the ostium. They were treated with intralesional injection of 
Table 2. Postoperative results, IOP, wound inflammation and scar resolution.

\begin{tabular}{|c|c|c|c|c|}
\hline Results & $\begin{array}{c}\text { Total } \\
(\mathbf{n}=\mathbf{3 8})\end{array}$ & $\begin{array}{c}\text { Group A } \\
(\mathbf{n}=\mathbf{2 0})\end{array}$ & $\begin{array}{c}\text { Group B (n } \\
\mathbf{= 1 8})\end{array}$ & P Value \\
\hline Success & 34 & 18 & 16 & $P=1.00$ \\
Failed & 4 & 2 & 2 & \\
\hline Yes & 2 & 2 & 0 & $P=0.48$ \\
No & 36 & 20 & 16 & \\
\hline Raised IOP $>15 \mathrm{~mm} \mathrm{Hg}$ & 25 & 16 & 8 & $P=0.04$ \\
\hline $\begin{array}{c}\text { First post operative wound inflammation } \\
\text { Minimal }\end{array}$ & 13 & 4 & 10 & \\
Moderate & 31 & 18 & 10 & $P=0.02$ \\
\hline Scar resolution & & & \\
<6 weeks & & 2 & 8 &
\end{tabular}

Composite Figure 1.
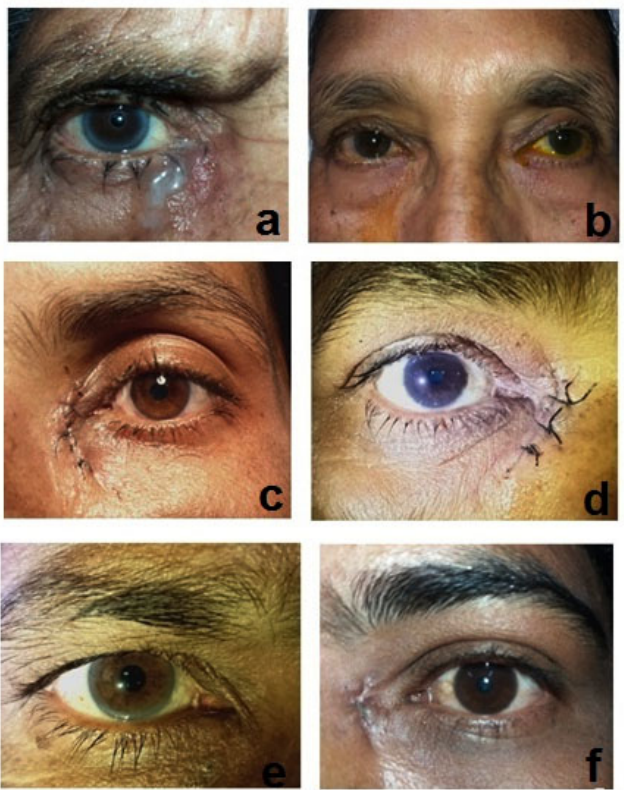

a . Positive regurgitation test in Right eye PANDO

b. Positive FDD test in Left eye PANDO.

c. Left eye minimal wound inflammation on first post operative day in a group A patient.

d. Right eye moderate wound inflammation on first post operative day in a group B patient

e. Right eye Cosmetically invisible scar at 6 weeks follow up in a group A patient.

f. Left eye cosmetically visible and blemish scar at 6 weeks follow up in a group B patient

$0.3 \mathrm{ml}$ of TMA $40 \mathrm{mg} / \mathrm{ml}$ and the final success rate was $75.55 \%$ (34/45 cases). In their study steroid was injected during the follow up period and in endonasal DCR osteotomy size relatively small and mucosal flaps are resected without anastomosis. These factors may be the reason for more number of failed cases in their study. It has been observed that depot steroid is more beneficial during the initial period of inflammation in reducing the fibrosis, scar formation and granulation tissue development [22]. Another explanation may be that we have used silicone stent in both the group. The stent it self has many positive out come on EXDCR. It enhances the lacrimal pump action, well opposes the puncta which improves the lacrimal flow during the closing phase of blinking, increased capillary function of canaliculi, prevents granuloma formation, by delaying the fibrosis, reduces the scarring and adhesion around the osteal opening $[5,12,14]$. However this difference is minimal $(\mathrm{P}=0.31)$.

Where as in a retrospective study Lee et al., [15] 15 eyes of PANDO 5 cases received introperative TMA and 100\% (5/5) had complete resolution of PANDO . Even thou Lee et al., [15]. reported success rate is more than our success rate of $90 \%(18 / 20)$ the difference is not significant $(\mathrm{P}=1.0)$. Moreover Lee et al., [15] patients were on systemic immunosuppressive agents for sarcoidosis, this may be reason for higher success rate.

Two patients in study group had raised IOP of more than $15 \mathrm{~mm}$ $\mathrm{Hg}$ during the follow up period. In general population 5-6 \% will have raised IOP of more than $15 \mathrm{~mm} \mathrm{Hg}$ for local and periocular steroid preparation and this will be $29-30 \%$ in primary open angle glaucoma patients [23]. We suggest that comprehensive 
glaucoma evaluation to be done before using the depot steroid in EXDCR patients.

We have noticed the following benefits in depot steroid received group. There was no requirement of topical steroid drops, post operative minimal inflammation around the incision wound and early resolution of wound scar. In a prospective study by Tanushree et al., [21] Nine patients had post DCR hypertropic scar and each received $0.2-0.4 \mathrm{ml}$ of TMA $40 \mathrm{mg} / \mathrm{ml} 2-3$ injections into the scar at 6 weekly interval. All the patients had resolution of hypertrophic scar. In our study $0.3-0.4 \mathrm{ml}$ depot steroid was injected around osteotomy and $0.1-0.2 \mathrm{ml}$ was pooled over the flap anastomoses before skin - muscle layers closed. This might have had positive outcome on scar development.

Even thou our study has failed to prove the assumption of intra operative injection of TMA will improve the positive outcome of EXDCR ( $\mathrm{P}=1.00)$. It has shown other non studied benefits like reduced postoperative inflammation, omission of topical steroid and early resolution of scar. Only concern is raised IOP in susceptible patients and converting to steroid induced glaucoma. Comprehensive glaucoma eye examination to be a manadatory in patients receiving TMA injection in EXDCR procedure. Lacunae in our study is small sample size.

\section{References}

[1]. Paulsen F. Pathophysiological aspects of PANDO, dacryolithiasis, dry eye, and punctum plugs. In Atlas of lacrimal surgery. Springer Science \& Business Media. 2007; Chapter $2 ; 15-27$.

[2]. Weber RK, Keerl R, Schaefer SD, Rocca RC. Atlas of lacrimal surgery. Springer Science \& Business Media. 2007 19; chapter 3: 3: 29-52.

[3]. Monka A, Zhungli S. Silicone Intubation in External Dacryocystorhinostomy. International J of Science and Research. 2015 Dec; 4(12): 1814-6.

[4]. Saiju R, Morse LJ, Weinberg D, M K Shrestha, S Ruit. Prospective randomized comparison of external DCR with an without silicone tube intubation. Br J Ophthalmol. 2009; 93:1220 -1222. PMID: 19515642.

[5]. Nuhoglu F, Sarıcı K, Ozdemir F E. Outcome of External Dacryocystorhinostomy with Bicanalicular Silicone Tube Stenting. JAREM. 2014; 4(3).

[6]. Anatolia AM. The effect of silicone tube intubation in external Dacryocystorhinostomy. Acta Med Anatol. 2015; 3(1):1-4.

[7]. Neena MP, Andrew RP. External dacryocystorhinostomy for the treatment of epiphora in patients with patent but non-functioning lacrimal systems. Br J Ophthalmol 2010; 94: 233-35. PMID: 19692388.

[8]. Bothra N, Wani RM, Ganguly A, Tripathy D, Rath S. Primary nonendoscopic endonasal versus external dacryocystorhinostomy in nasolacrimal duct obstruction in children. Indian J Ophthalmol 2017; 65: 1004-7. PMID: 29044069.

[9]. Mukhtar S A, Jamil A Z, Ali Z. Efficacy of External Dacryocystorhinostomy (DCR) with and without Mitomycin-C in Chronic Dacryocystitis. Journal of the College of Physicians and Surgeons Pakistan. 2014; 24(10): 732-735. PMID: 25327916.

[10]. Nair AG, Ali MJ. Mitomycin C in Dacrycystorhinostomy: From experimental to implementation and the road ahead: A Review. Ind J ophthalmol. 2015; 63: 335-9. PMID: 26044474.

[11]. Aerin Jo A, Lee S H, Song W C, Shin H J. Effects of ostium granulomas and intralesional steroid injections on the surgical outcome in endoscopic dacryocystorhinostomy. Graefe's Archive for Clinical and Experimental Ophthalmology. 2018; 256(10): 1993-2000. PMID: 29858678.

[12]. Pradeep B, Rajendran B. Double canalicular single tube intubation in DCR. In J Ophthalmol 1983; 31:329 -30.

[13]. Elhesy A. Effect of lacrimal silicone intubation in persistant epiphora after an anatomically successful but functionally failed dacryocystorhinostomy (Mansoura technique). Journal of Egyptian Ophthalmological Society. 2013; 106: 74-77.

[14]. Connell P P, Fulcher TP, Chacko E, Connor M J O, Moriarty P. Long term follow up of nasolacrimal intubation in adults. Br J Ophthalmol. 2006; 90: 435-436. PMID: 16547322.

[15]. Lee BJ, Nelson CC, Lewis CD, Perry JD. External dacryocystorhinostomy outcomes in sarcoidosis patients. Ophthal Plast Reconstr Surg. 2012; 28: 47-49. PMID: 22082600.

[16]. Sloas HS, Starling J, Galentine PG, Hargett NA. Treatment of chalazion with injectable triamcinolone. Ann Ophthalmol. 1983; 15: 78- 80.

[17]. Ho SY, Lai JSM. Subcutaneous steroid injection as treatment for chalazion: Prospective case series. KKMJ. 2002; 8: 18 - 20. PMID: 11861988.

[18]. Hadas Stiebel-Kalish, Eyal Robenshtok, Murat Hasanreisoglu, David Ezrachi, Ilan Shimon, Leonard Leibovici. Treatment modalities for Grave's ophthalmopathy: systemic review and metaanalysis. J Clin Endocrinol Metab. 2009; 94: 2708-2716. PMID: 19491222.

[19]. Ockrim ZK, Sivaprasad S, Falk S, S Roghani, C Bunce, Z Grego, et al. Intravitreal Triamcinolone versus laser photocoagulation for persistant diabetic macular oedema. Br J Opthalmol. 2008; 92: 795-799. PMID: 18420749.

[20]. Burk SE, Da Mata AP, Snyder ME, Susan Schneider, Robert H Osher, Robert J Cionni. Visualising vitreous using Kenalog suspension. J cataract Refract Surg. 2003; 29: 645-651. PMID: 12686230.

[21]. Tanushree V, Venkategouda HT. 5 Fluorouracil versus Triamcinolone injecion in the management of Periocular scar. IJOER. 2016; 4(6): 231- 232.

[22]. Jimmy D B, Siret D J. Clinical Ocular Pharmocology.Elsevier inc V Edi 2008. Chapter 12; Anti inflammatory drugs : 221-223

[23]. Mallik Y K, Joel S M, David L E. Chandler and Grant's Glaucoma .V Edition, Slack Incorporated 2013, Cortico steroid Glaucoma ;Chapter 44 : $424-429$. 